\title{
Pharmacokinetics of Ethanol After Oral Administration in the Fasting State ${ }^{1}$
}

\author{
Paul K. Wilkinson, ${ }^{2,3}$ Allen J. Sedman, ${ }^{2,4}$ Ermelinda Sakmar, ${ }^{2}$ \\ Donald R. Kay, ${ }^{2}$ and Johw G. Wagner ${ }^{2,5}$
}

Received June 1, 1976-Final Aug. 13, 1976

\begin{abstract}
A nonlinear relationship between the total area under the blood ethanol concentration-time curve and the orally administered dose $(\mathrm{mg} / \mathrm{kg}$ ) of ethanol was observed in fasting subjects. $A$ preliminary model, based on physiological considerations, was elaborated and shown, for the first time, to describe the entire time course of blood alcohol concentrations after four different doses of alcohol. The model could be refined by further experimentation.
\end{abstract}

KEY WORDS: nonlinear pharmacokinetics; Michaelis-Menten kinetics; gastric emptying rate; blood alcohol concentrations.

\section{INTRODUCTION}

Ethanol ingested on an empty stomach is very rapidly absorbed as it passes into the small intestine (1-3). When moderate amounts of ethyl alcohol are administered in solution, maximum blood alcohol concentrations are attained with stronger solutions. Very concentrated solutions are

Supported by Grant 1R01 AA00683-01 A1 from the National Institute on Alcohol Abuse and Alcoholism, Alcohol, Drug Abuse and Mental Health Administration, Rockville, Md.

${ }^{1}$ Abstracted in part from a dissertation by Paul K. Wilkinson, submitted to The University of Michigan in partial fulfiliment of the Doctor of Philosophy degree requirements.

${ }^{2}$ College of Pharmacy and Upjohn Center for Clinical Pharmacology, The University of Michigan, Ann Arbor, Michigan 48109.

${ }^{3}$ Robert Lincoln McNeil Memorial Fellow of the American Foundation for Pharmaceutical Education. Present address: School of Pharmacy, Auburn University, Auburn, Alabama 36830.

${ }^{4}$ Present address: School of Medicine, Washington University, St. Louis, Missouri 63110.

${ }^{5}$ Address correspondence to Dr. John G. Wagner, Upjohn Center for Clinical Pharmacology, The University of Michigan Medical Center, Ann Arbor, Michigan 48109. 
absorbed relatively slowly following oral ingestion because the high concentrations inhibit gastic peristalsis and cause pylorospasm $(1,4)$, thus delaying the arrival of the alcohol in the small intestine. Large amounts of alcohol taken in dilute solution are also absorbed relatively slowly $(1,5)$, possibly as a result of a volume effect on gastric emptying rate (6). Mellanby (5) reported different rates of absorption in man when equal amounts of alcohol were ingested in the form of whiskey $(19 \% \mathrm{v} / \mathrm{v})$ or stout $(5 \% \mathrm{v} / \mathrm{v})$. He also observed (7) that the absorption rate from $20 \%$ alcohol solution was less than 4 times faster than that of an equal volume of a $5 \%$ alcohol solution. He concluded that this result was produced by the inhibitory effect of the more concentrated solution on the stomach. Mitchell and Curzon (8) reported that "with higher concentrations, absorption is slowed due to slower evacuation from the stomach." Alcohol in solution has been shown to retard the gastric emptying rate in man (9), as measured by the increase in the volume of a test meal remaining in the stomach at a fixed time following the administration of solutions of increasing alcohol concentrations.

Numerous workers $(2,10-24)$ have measured, either directly or via breath analysis, blood alcohol concentrations following oral administration of ethanol to man and small animals under both fasting and nonfasting conditions, and in conjunction with drugs which alter gastrointestinal motility. Most investigators (10-19) have not measured blood alcohol concentrations at early times; the first sampling time was usually $\frac{1}{2}-1$ hr after dosing. To accurately define the entire time course for pharmacokinetic purposes, early samples must be obtained as well as numerous samples at the tail end of the curve (22).

Traditionally, it has been assumed that the kinetics of elimination of ethanol from human blood can be described as zero order, i.e., independent of the blood concentration (above about $2-3 \mathrm{~mm}$ or $0.009-0.14 \mathrm{mg} / \mathrm{ml}$ ). Although several studies (25-28) have indicated non-zero-order elimination kinetics, the former concept still persists $(29,30)$. In a preliminary report of some of the data in this article, Wagner et al. (25) gave substantial evidence that the elimination of alcohol from human blood obeys MichaelisMenten kinetics and not zero-order kinetics.

The study to be discussed was undertaken to (a) accurately define the entire time course of blood alcohol concentrations in fasting, adult, male volunteers; (b) determine the dose-response relationships for area under the curve and peak alcohol concentration; (c) determine the nature of the kinetics of absorption of ethanol in fasting subjects; and (d) elaborate a preliminary model for alcohol pharmacokinetics which could explain with reasonable accuracy the entire time course of blood alcohol concentrations after several doses. 
Table 1. Dosage Schedule and Treatments

\begin{tabular}{cccccc}
\hline & & \multicolumn{4}{c}{ Phase } \\
\cline { 3 - 6 } Group & Subjects & I & II & III & IV \\
\hline II & 1,2 & $\mathrm{~A}^{a}$ & $\mathrm{~B}$ & $\mathrm{D}$ & $\mathrm{C}$ \\
II & 3,4 & $\mathrm{~B}^{b}$ & $\mathrm{C}$ & $\mathrm{A}$ & $\mathrm{D}$ \\
III & 5,6 & $\mathrm{C}^{c}$ & $\mathrm{D}$ & $\mathrm{B}$ & $\mathrm{A}$ \\
IV & 7,8 & $\mathrm{D}^{d}$ & $\mathrm{~A}$ & $\mathrm{C}$ & $\mathrm{D}$ \\
\hline
\end{tabular}

a $15 \mathrm{ml}$ of $95 \%$ ethanol diluted to $150 \mathrm{ml}$ with orange juice.

${ }^{b} 30 \mathrm{ml}$ of $95 \%$ ethanol diluted to $150 \mathrm{ml}$ with orange juice.

${ }^{\circ} 45 \mathrm{ml}$ of $95 \%$ ethanol diluted to $150 \mathrm{ml}$ with orange juice.

${ }^{d} 60 \mathrm{ml}$ of $95 \%$ ethanol diluted to $150 \mathrm{ml}$ with orange juice.

\section{EXPERIMENTAL}

\section{Protocol}

Eight normal adult white male volunteers between the ages of 21 and 27 and weighing between 66 and $89 \mathrm{~kg}$, with normal vital signs and laboratory screening values, were selected (see Table III). The study was performed using a latin square design with four groups of two subjects, arranged in order of increasing body weight. Each subject received 15,30,45, and $60 \mathrm{ml}$ of $95 \%$ ethanol in orange juice (total volume of each dose was $150 \mathrm{ml}$ ) orally, at 1-week intervals according to the dosage schedule shown in Table I. The subjects fasted from $10 \mathrm{hr}$ prior to dosing until $3 \mathrm{hr}$ after administration of the alcohol. No alcoholic beverages (other than the prescribed alcohol) were consumed from 3 days preceding each phase of the study until the completion of that phase.

Just prior to dosing and at strategic sampling times following the 15, 30, 45 , and $60 \mathrm{ml}$ doses of $95 \%$ ethanol (by assay), 18, 25, 23, and 27 capillary blood samples, respectively, were collected. Each sample was collected from a fingertip, after lancing, in a 50- $\mu$ l calibrated microsampling capillary tube. The blood samples were immediately mixed with an equal volume of internal standard solution, transferred to 6 -ml amber glass serum vials (31), frozen, and kept in the frozen state until just prior to assay.

\section{Analytical Method}

Fifty-microliter capillary blood samples were assayed for ethyl alcohol according to the head-space gas chromatographic method of Wilkinson et al. (31). The analysis was performed on a Varian 2100 gas chromatograph equipped with flame ionization detectors. 


\section{Computer Analysis of Experimental Data}

The average blood alcohol concentrations over the entire time course for all four doses were simultaneously fitted to the one-compartment open model with Michaelis-Menten elimination kinetics and input to blood subject to feedback regulation as shown in Scheme I. These data were fitted using the nonlinear least squares regression program, NONLIN (32), employing an IBM 370/168 digital computer.

$$
\left\{\begin{array}{l}
D \text { at } \\
t=0
\end{array}\right\} \stackrel{\leftrightarrow}{S} \stackrel{k_{e}}{\hookrightarrow} I \stackrel{k_{a}}{\rightarrow} B \stackrel{V_{m} \cdot K_{m}}{\longrightarrow} \text { metabolites }
$$

Scheme I

In Scheme I, $D$ represents the dose (grams of absolute alcohol initially placed in the stomach), $S$ represents the amount of alcohol at time $t$ that remains in the stomach, $I$ represents the amount of alcohol at time $t$ at the primary absorption site in the small intestine, $B$ represents the amount of alcohol at time $t$ in the blood and other fluids of distribution, $k_{e}$ is the first-order rate constant for gastric emptying, $k_{a}$ is the first-order rate constant for the absorption of alcohol from the small intestine, $V_{m}$ is the maximum velocity $[\mathrm{mg} /(\mathrm{ml} \times \mathrm{hr})]$, and $K_{m}$ is the Michaelis constant $(\mathrm{mg} / \mathrm{ml})$ for the elimination of alcohol from the body. $B$ is assumed to be distributed in a volume, $V$. The assumed equation giving $k_{e}$ and the differential equations corresponding to Scheme I, which were utilized in the simultaneous computer fitting, are as follows:

$$
\begin{aligned}
k_{e} & =\left(k_{e}\right)_{\max } /\left(1+a D^{2}\right) \\
d I / d t & =k_{e}(F D / V) e^{-\left[k_{e} t\right]-k_{a} I} \\
d B / d t & =k_{a} I-V_{m} B /\left(K_{m}+B\right)
\end{aligned}
$$

In equation $2, F$ is the fraction of the dose which is absorbed and appears in the general circulation; this fraction is taken as unity (complete absorption and complete availability) for the 45 and $60 \mathrm{ml}$ doses, but two parameters, $F_{15 \mathrm{ml}}$ and $F_{30 \mathrm{ml}}$, were estimated for the 15 and $30 \mathrm{ml}$ doses of $95 \%$ ethanol, respectively.

In the fittings, the " $I$ " and " $B$ " were actually in concentration units, and were the respective amounts of alcohol divided by the volume, $V$. The " $B$ " in equation 3 was the blood alcohol concentration in $\mathrm{mg} / \mathrm{ml}$. The doses, $D$, were $11.2,22.4,33.6$, and $45.0 \mathrm{~g}$ of absolute alcohol, corresponding to doses of $15,30,45$, and $60 \mathrm{ml}$ of $95 \%$ alcohol, respectively. 

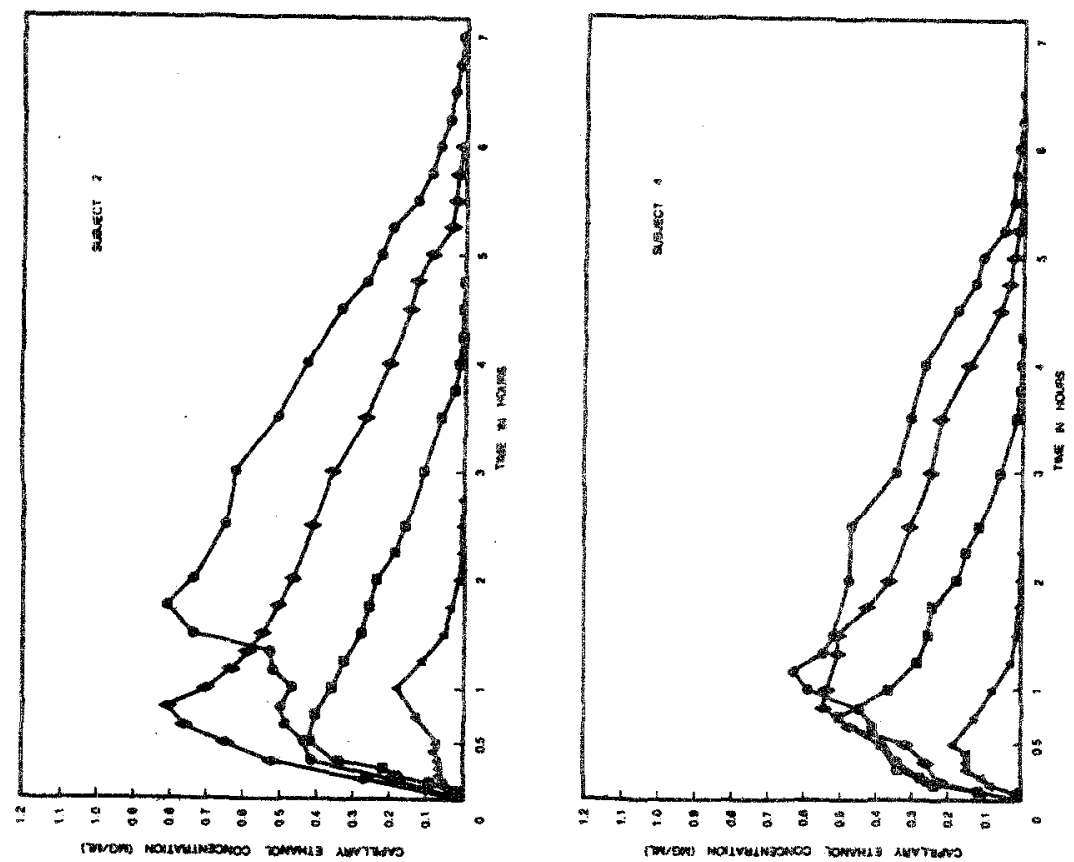

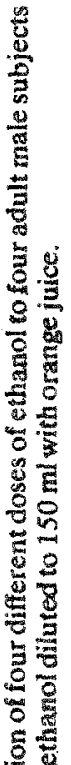

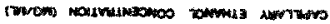

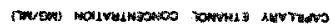
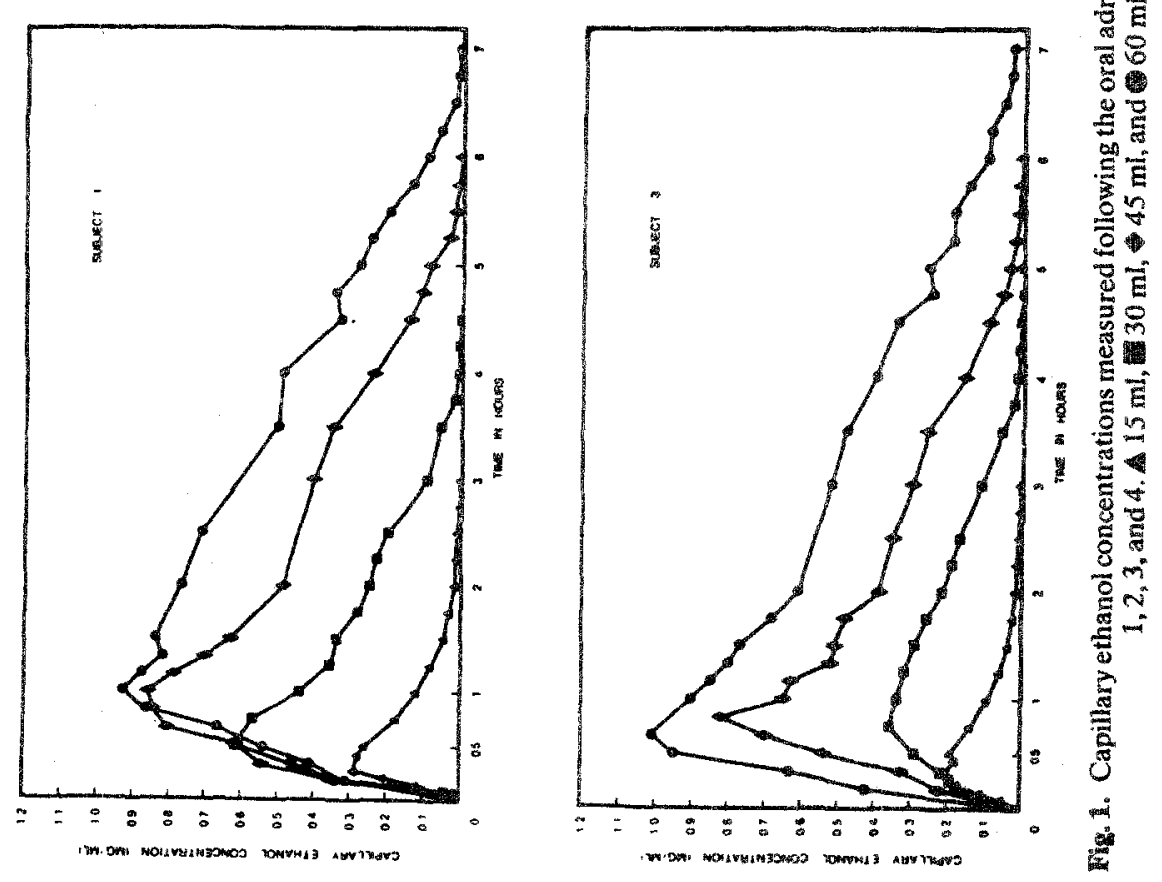

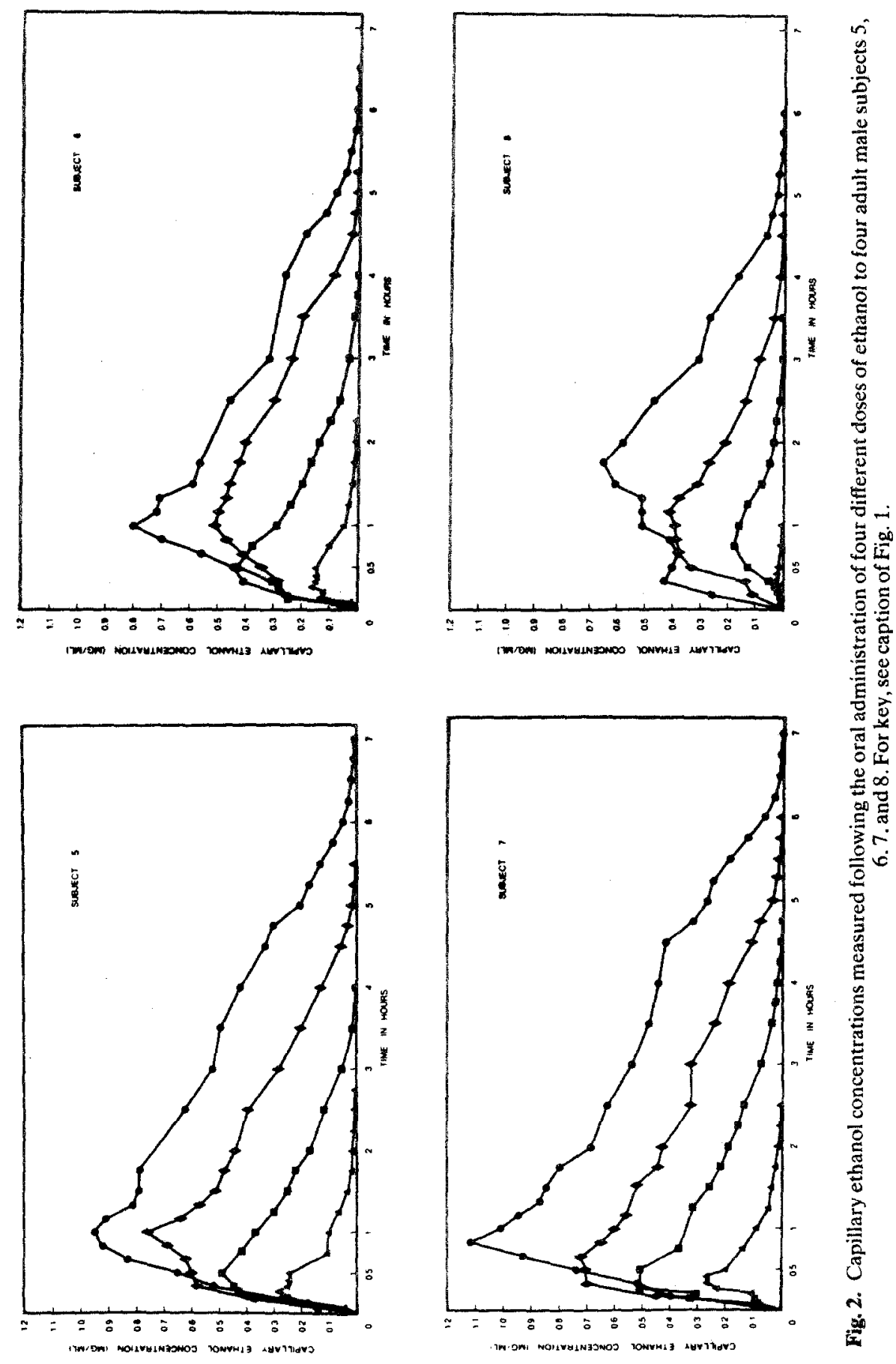


\section{RESULTS AND DISCUSSION}

Figures 1 and 2 show the capillary ethanol concentration-time profiles for the eight subjects, while the mean capillary ethanol concentrations following the oral administration of the four different doses of ethanol are presented in Table II. These data were characterized by (a) a pseudolinear

Table II. Mean Fasting Capillary Ethanol Concertration (mg/mi) at Indicated Sampling Times Following the Oral Administration of Four Different Doses of Ethanol to Eight Aduit Male Subjects

\begin{tabular}{lllll}
\hline & \multicolumn{5}{c}{$\begin{array}{c}\text { Concentration }(\mathrm{mg} / \mathrm{ml}) \text { after } 95 \% \\
\text { ethanol oral dose of }\end{array}$} \\
\cline { 2 - 5 }$(\mathrm{hr})$ & $15 \mathrm{ml}$ & $30 \mathrm{ml}$ & $45 \mathrm{ml}$ & $60 \mathrm{ml}$ \\
\hline 0. & 0. & 0. & 0. & 0. \\
0.067 & 0.032 & 0.071 & - & - \\
0.133 & 0.096 & 0.019 & - & - \\
0.167 & - & - & 0.28 & 0.30 \\
0.2 & 0.13 & 0.25 & - & - \\
0.267 & 0.17 & 0.30 & - & - \\
0.333 & 0.16 & 0.31 & 0.42 & 0.46 \\
0.417 & 0.17 & - & - & - \\
0.5 & 0.16 & 0.41 & 0.51 & 0.59 \\
0.667 & - & - & 0.61 & 0.66 \\
0.75 & 0.12 & 0.40 & - & - \\
0.833 & - & - & 0.65 & 0.71 \\
1.0 & 0.090 & 0.33 & 0.63 & 0.77 \\
1.167 & - & - & 0.59 & 0.75 \\
1.25 & 0.062 & 0.29 & - & - \\
1.33 & - & - & 0.53 & 0.70 \\
1.5 & 0.033 & 0.24 & 0.50 & 0.71 \\
1.75 & 0.020 & 0.22 & 0.43 & 0.72 \\
2.0 & 0.012 & 0.18 & 0.40 & 0.64 \\
2.25 & 0.0074 & 0.15 & - & - \\
2.5 & 0.0052 & 0.12 & 0.32 & 0.57 \\
2.75 & 0.0034 & - & - & - \\
3.0 & 0.0024 & 0.069 & 0.28 & 0.45 \\
3.5 & - & 0.034 & 0.22 & 0.43 \\
3.75 & - & 0.017 & - & - \\
4.0 & - & 0.010 & 0.15 & 0.36 \\
4.25 & - & 0.0068 & - & - \\
4.5 & - & 0.0052 & 0.081 & 0.27 \\
4.75 & - & 0.0037 & 0.059 & 0.22 \\
5.0 & - & - & 0.042 & 0.18 \\
5.25 & - & - & 0.021 & 0.15 \\
5.5 & - & - & 0.014 & 0.11 \\
5.75 & - & - & 0.0099 & 0.079 \\
6.0 & - & - & 0.0056 & 0.050 \\
6.25 & - & - & - & 0.037 \\
6.5 & - & - & - & 0.020 \\
6.75 & - & - & - & 0.017 \\
7.0 & - & & & 0.012 \\
\hline & & - & - & - \\
\hline
\end{tabular}


Table III. Vital Statistics of Subjects, ${ }^{a}$ Doses, Areas Under the Concentration-Time Curves, and Peak Concentrations of Ethanol

\begin{tabular}{|c|c|c|c|c|c|c|c|c|}
\hline \multirow[b]{2}{*}{ Subject } & \multirow[b]{2}{*}{$\begin{array}{c}\text { Bady } \\
\text { weight } \\
\text { (kg) }\end{array}$} & \multirow[b]{2}{*}{$\begin{array}{l}\text { Height } \\
\text { (cm) }\end{array}$} & \multirow{2}{*}{$\begin{array}{l}\text { Body } \\
\text { surface } \\
\text { area } \\
\left(\mathrm{m}^{2}\right)\end{array}$} & \multirow[b]{2}{*}{$\begin{array}{l}\text { Age } \\
(\mathrm{yr})\end{array}$} & \multicolumn{2}{|r|}{ Dose } & \multirow[b]{2}{*}{$\begin{array}{c}\text { Area }^{b} \\
{[(\mathrm{mg} / \mathrm{ml})} \\
\times \mathrm{hr}]\end{array}$} & \multirow[b]{2}{*}{$\begin{array}{c}\text { Peak } \\
(\mathrm{mg} / \mathrm{ml})\end{array}$} \\
\hline & & & & & $\begin{array}{c}\mathrm{ml} \text { of } \\
95 \% \\
\text { alcohol }\end{array}$ & $\begin{array}{l}\mathrm{g} \text { of absolute } \\
\text { alcohol } / \mathrm{kg}\end{array}$ & & \\
\hline 1 & 65.9 & 172 & 1.78 & 26 & $\begin{array}{l}15 \\
30 \\
45 \\
60\end{array}$ & $\begin{array}{l}0.171 \\
0.341 \\
0.512 \\
0.683\end{array}$ & $\begin{array}{l}0.258 \\
1.017 \\
2.211 \\
3.198\end{array}$ & $\begin{array}{l}0.29 \\
0.62 \\
0.86 \\
0.93\end{array}$ \\
\hline 2 & 70.5 & 178 & 1.87 & 23 & $\begin{array}{l}15 \\
30 \\
45 \\
60\end{array}$ & $\begin{array}{l}0.160 \\
0.319 \\
0.479 \\
0.638\end{array}$ & $\begin{array}{l}0.169 \\
0.834 \\
1.996 \\
2.727\end{array}$ & $\begin{array}{l}0.18 \\
0.42 \\
0.81 \\
0.81\end{array}$ \\
\hline 3 & 70.5 & 172 & 1.83 & 27 & $\begin{array}{l}15 \\
30 \\
45 \\
60\end{array}$ & $\begin{array}{l}0.160 \\
0.319 \\
0.479 \\
0.638\end{array}$ & $\begin{array}{l}0.196 \\
0.778 \\
1.715 \\
3.089\end{array}$ & $\begin{array}{l}0.20 \\
0.36 \\
0.82 \\
1.01\end{array}$ \\
\hline 4 & 71.4 & 178 & 1.89 & 23 & $\begin{array}{l}15 \\
30 \\
45 \\
60\end{array}$ & $\begin{array}{l}0.158 \\
0.315 \\
0.473 \\
0.630\end{array}$ & $\begin{array}{l}0.147 \\
0.782 \\
1.437 \\
1.873\end{array}$ & $\begin{array}{l}0.19 \\
0.51 \\
0.55 \\
0.63\end{array}$ \\
\hline 5 & 75.0 & 188 & 2.00 & 21 & $\begin{array}{l}15 \\
30 . \\
45 \\
60\end{array}$ & $\begin{array}{l}0.150 \\
0.300 \\
0.450 \\
0.600\end{array}$ & $\begin{array}{l}0.215 \\
0.781 \\
1.733 \\
2.968\end{array}$ & $\begin{array}{l}0.28 \\
0.49 \\
0.76 \\
0.95\end{array}$ \\
\hline 6 & 75.0 & 178 & 1.92 & 23 & $\begin{array}{l}15 \\
30 \\
45 \\
60\end{array}$ & $\begin{array}{l}0.150 \\
0.300 \\
0.450 \\
0.600\end{array}$ & $\begin{array}{l}0.130 \\
0.682 \\
1.322 \\
2.046\end{array}$ & $\begin{array}{l}0.16 \\
0.43 \\
0.51 \\
0.80\end{array}$ \\
\hline 7 & 79.5 & 178 & 1.98 & 21 & $\begin{array}{l}15 \\
30 \\
45 \\
60\end{array}$ & $\begin{array}{l}0.142 \\
0.283 \\
0.424 \\
0.566\end{array}$ & $\begin{array}{l}0.200 \\
0.836 \\
1.832 \\
3.249\end{array}$ & $\begin{array}{l}0.27 \\
0.51 \\
0.72 \\
1.12\end{array}$ \\
\hline 8 & 88.6 & 179 & 2.07 & 21 & $\begin{array}{l}15 \\
30 \\
45 \\
60\end{array}$ & $\begin{array}{l}0.127 \\
0.254 \\
0.382 \\
0.508\end{array}$ & $\begin{array}{l}0.011 \\
0.212 \\
0.775 \\
1.735\end{array}$ & $\begin{array}{l}0.025 \\
0.18 \\
0.41 \\
0.65\end{array}$ \\
\hline
\end{tabular}

${ }^{a}$ All subjects were white and were either students or recent graduates. Only subject 7 was a smoker.

${ }^{b}$ The areas under the concentration-time curves were estimated with the trapezoidal rule. 
phase, apparent after the peak concentration had been attained, which extended down to a blood ethanol concentration of about $0.20 \mathrm{mg} / \mathrm{ml}$, followed by a portion, below $0.20 \mathrm{mg} / \mathrm{ml}$, in which the concentration profiles tended to be curved with time, and (b) a nonlinear relationship between the area under the concentration-time curve and the oral dose $(\mathrm{mg} / \mathrm{kg})$ of ethanol administered.

Table III gives areas under the concentration-time curves, and Fig. 3 shows the area as a function of the administered dose $(\mathrm{mg} / \mathrm{kg})$ for all eight subjects. The upward curvature of the data in Fig. 3 is readily apparent, indicating a nonlinearity in the area-dose relationship. Theory requires that the data pass through the origin, i.e., zero area with zero dose. Any trend line drawn from the 0,0 point through the means or medians of the area distribution for each of the four doses (on a weight basis) would be curved and not a straight line.

From the data obtained in this study, the relationship between peak ethanol concentration and dose can be expressed as a linear function. Table

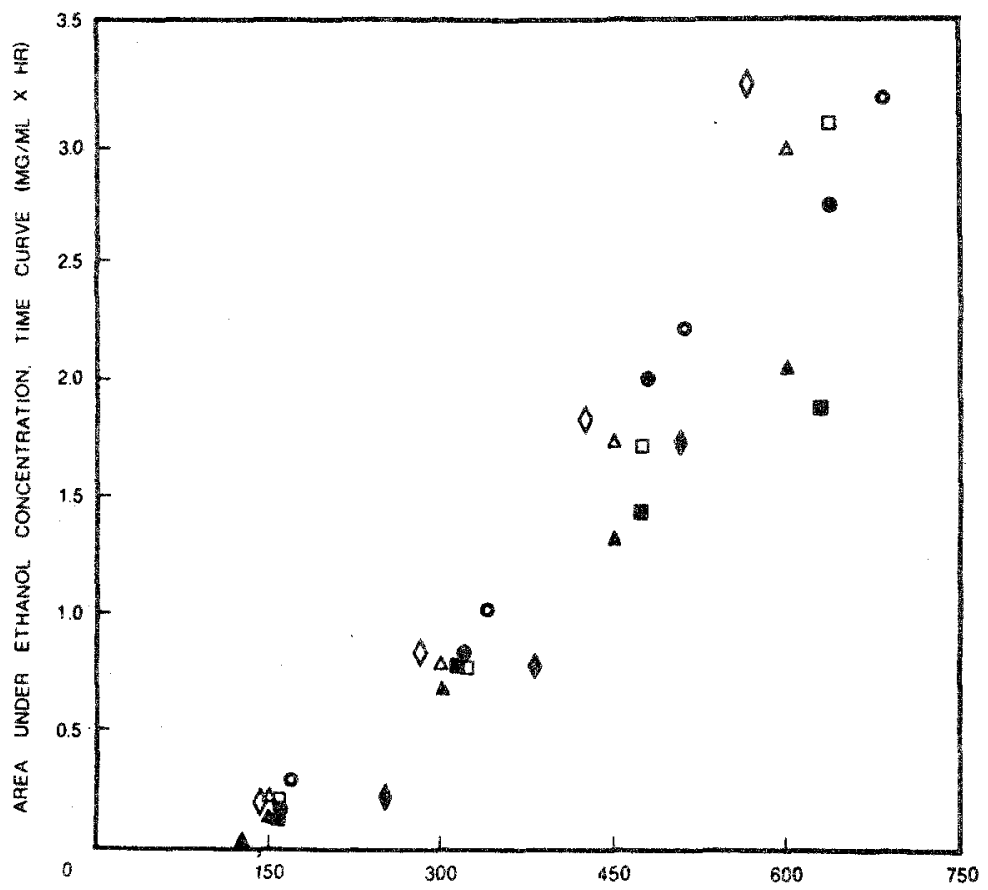

Fig. 3. Area under the ethanol concentration-time curve as a function of dose following the oral administration of four different doses of ethanol to eight adult male subjects. O Subject 1 , subject $2, \square$ subject 3 , 1 subject $4, \Delta$ subject 5, subject $6, \diamond$ subject 7 , and subject 8 . 
Table IV. Parameters of the Least-Squares Linear Regression Lines ${ }^{\star}$ Relating Peak Alcohol Concentration $(\mathrm{mg} / \mathrm{ml})$ to Dose of Alcohol Expressed as Grams of Absolute Alcohol per Kilogram of Body Weight Following the Oral Administration of Ethanol to Eight Adult Male Subjects

\begin{tabular}{|c|c|c|c|c|}
\hline Subject & Intercept ( $a$ ) & Slope $(b)$ & & $\begin{array}{l}\text { Slope of line } \\
\text { forced through } \\
\text { originc }\end{array}$ \\
\hline \multirow[t]{2}{*}{$\begin{array}{l}1 \\
2 \\
3 \\
4 \\
5 \\
6 \\
7 \\
8\end{array}$} & $\begin{array}{r}0.135 \\
-0.015 \\
-0.125 \\
0.130 \\
0.050 \\
-0.25 \\
-0.035 \\
-0.210\end{array}$ & $\begin{array}{l}1.27 \\
1.43 \\
1.81 \\
0.863 \\
1.52 \\
1.33 \\
1.95 \\
1.66\end{array}$ & $\begin{array}{l}0.965 \\
0.949 \\
0.981 \\
0.909 \\
0.998 \\
0.980 \\
0.989 \\
0.995\end{array}$ & $\begin{array}{l}1.53 \\
1.15 \\
1.55 \\
1.14 \\
1.63 \\
1.28 \\
1.87 \\
1.11\end{array}$ \\
\hline & $\begin{array}{c}-0.012 \\
-\end{array}$ & $\begin{array}{l}1.48 \\
23.1\end{array}$ & & $\begin{array}{l}1.41 \\
19.8\end{array}$ \\
\hline
\end{tabular}

${ }^{a}$ Peak $=a+b$ (dose).

${ }^{b} r$ is the corretation coefficient.

${ }^{c}$ Peak $=$ (slope) $($ dose $)$.

III gives the peak ethanol concentrations, and Table IV gives the parameters of the least-squares linear regressions of peak ethanol concentration on dose. Figure 4 shows the peak ethanol concentrations as a function of dose for all eight subjects.

The slope of the pseudolinear decline of blood ethanol concentrations has been shown to be dose dependent, such that the slope increases with increase in dose (25). Table $\mathrm{V}$ summarizes the initial alcohol concentration $\left(C_{0}\right)$ used to estimate the slopes of the pseudolinear decline of capillary blood ethanol concentrations and the absolute values of the slope for all eight subjects. Wagner (33) has shown theoretically that evaluation of the apparently linear decline as a linear component yields an increase in absolute value of the slope with increase in dose (or $C_{0}$ ) and a linear relationship between the reciprocal of the slope, $1 / k_{0}$, and the reciprocal of the initial concentration, $1 / C_{0}$, when elimination kinetics are those of Michaelis and Menten (34). Wagner et al. (25) have shown that the average terminal blood alcohol concentrations following all four doses of ethanol can be fitted simultaneously to a modification of the integrated form of the Michaelis-Menten equation $(28,34)$ shown as

$$
C_{0}-C+K_{m} \ln \left(C_{0} / C\right)=V_{m}\left(t-t_{1}\right)
$$

where $C_{0}$ is the initial concentration, $C$ is the concentration at time $t, K_{m}$ is the Michaelis constant, $V_{m}$ is the maximal velocity, and $t_{1}$ is a lag time to 


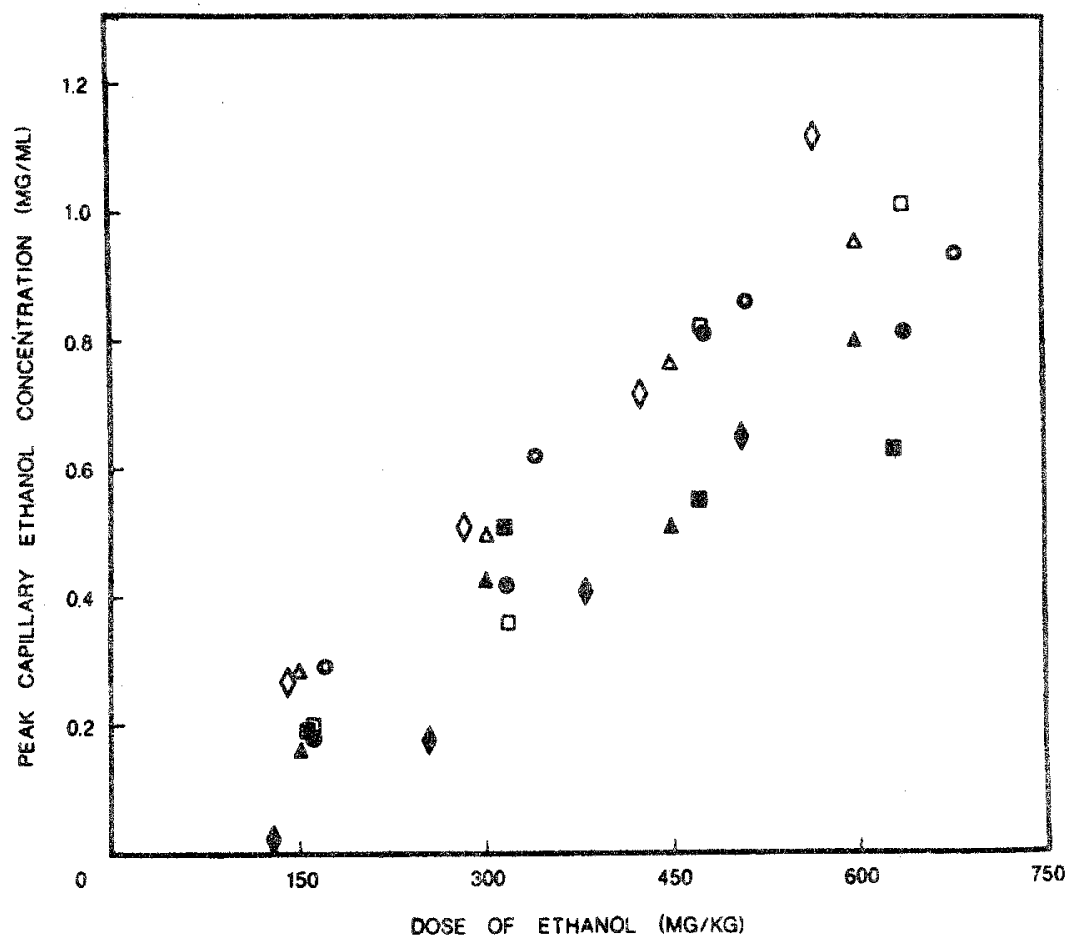

Fig. 4. Peak capillary ethanol concentration as a function of dose following the oral administration of four different doses of ethanol to eight adult male subjects. For key, see caption of Fig. 3.

Table V. Relationship of the Absolute Value of the Slope of the Apparently Linear Decline of Blood Alcohol Concentrations to Dose and Initial Blood Alcohol Concentration

\begin{tabular}{|c|c|c|c|c|c|}
\hline \multirow{2}{*}{$\begin{array}{l}\text { Dose of } 95 \% \\
\text { ethand }(\mathrm{ml})\end{array}$} & \multicolumn{2}{|c|}{$\begin{array}{c}\text { Initial alcohol } \\
\text { concentration }(\mathrm{mg} / \mathrm{mi})\end{array}$} & \multicolumn{3}{|c|}{$\begin{array}{l}\text { Absolute value of slope of apparent } \\
\text { linear decline }[\mathrm{mg} /(\mathrm{ml} \times \mathrm{hr})]\end{array}$} \\
\hline & Average & Range & Average & Range & C.V. $(\%)$ \\
\hline 15 & 0.065 & $0.025-0.12$ & 0.074 & $0.034-0.119$ & 44.1 \\
\hline 30 & 0.26 & $0.078-0.36$ & 0.121 & $0.071-0.144$ & 19.0 \\
\hline 45 & 0.43 & $0.31-0.51$ & 0.137 & $0.104-0.173$ & 16.6 \\
\hline \multirow[t]{2}{*}{60} & 0.63 & $0.47-0.78$ & 0.147 & $0.135-0.562$ & 19.3 \\
\hline & & & $0.163^{b}$ & $0.128-0.232^{6}$ & 19.9 \\
\hline
\end{tabular}

"The first alcohol concentration used to estimate the slope of the apparent linear decline of blood alcohol.

${ }^{b}$ The reciprocal of the intercept of a double reciprocal plot of $1 / k_{0}$ vs. $1 / C_{0}$ for the four points for each subject, where $k_{0}$ is the absolute value of the slope of the apparently linear decline and $C_{0}$ is the initial alcohol concentration. 
adjust for the duration of the absorption-distribution phase following a given dose of ethanol.

To determine the nature of the absorption kinetics of ethanol in fasting subjects, the Wagner-Nelson method (35), modified for Michaelis-Menten elimination kinetics (36) (equation 5), was applied to the mean blood alcohol concentration data for all four doses:

$$
A_{T} / V=C_{T}+\int_{0}^{T} V_{m} C /\left(K_{m}+C\right) d t
$$

where $A_{T}$ is the amount absorbed to some time $T, V$ is the volume of distribution, $C_{T}$ is the blood alcohol concentration at time $T$, and $V_{m}$ and $K_{m}$ are defined above; the maximum value of this function for each set of data is termed $A_{\infty} / V$. The semilogarithmic plots of the amount not absorbed divided by the volume of distribution, $\left(A_{\infty}-A_{T}\right) / V$, vs. time are shown in Fig. 5. If the oral absorption of ethanol was a single first-order process, then all the semilogarithmic plots would be straight lines with the same slope,

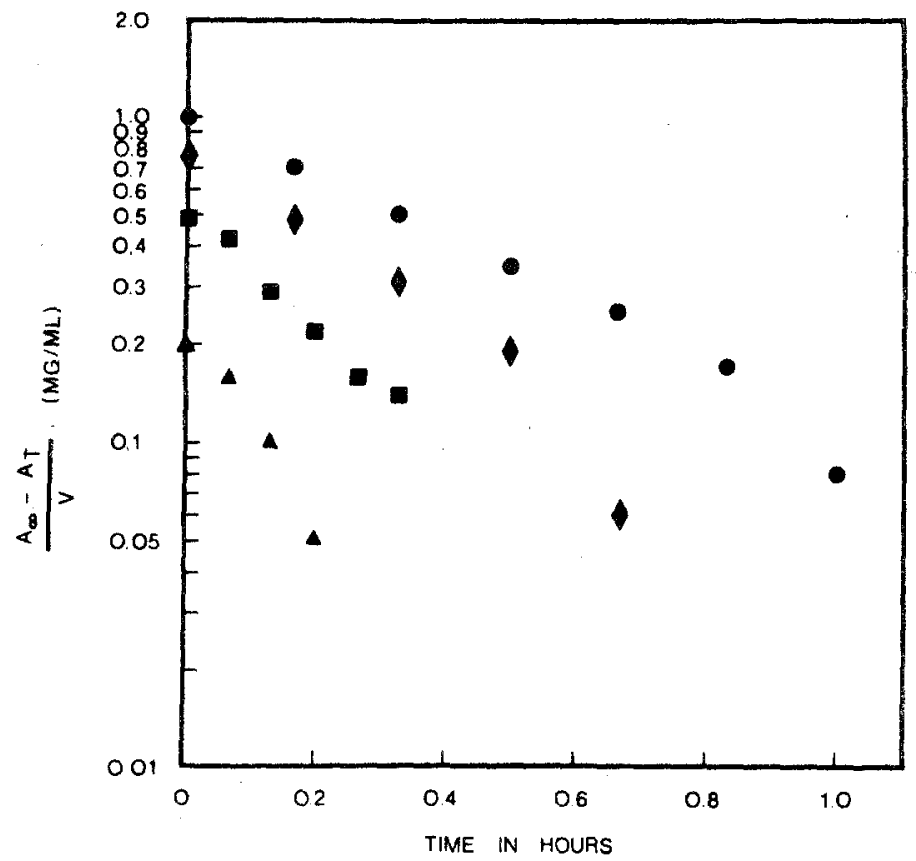

Fig. 5. Semilogarithmic plot of amount not absorbed divided by the volume of distribution as a function of time from mean blood alcohol concentrations following the oral administration of four different doses of ethanol to eight adult male subjects. For key, see caption of Fig. 1. 
equal to the first-order absorption rate constant, $k_{a}$. As seen in Fig. 5 , the trend of the points for each of the doses form a curved line on the semilogarithmic graph paper. Since the curves are not parallel, the absorption of ethanol in the fasting state appears to be nonlinear and dose dependent.

Ethanol has been shown to retard the gastric empiying rate, as indicated by the increase in residual test meals in the stomach after a set time with increasing alcohol concentration in the test meal (9). Therefore, it would seem reasonable to postulate some form of feedback mechanism which would alter the rate of transfer of alcohol from the stomach into the small intestine where most of the alcohol would be expected to be absorbed.

The model (Scheme I) is of the feedback type because of equation 1 , which assumes that the rate constant for stomach emptying of the $150 \mathrm{ml}$ total volume (alcohol plus orange juice) is dependent on the dose of alcohol administered and physiological considerations. Several studies $(9,37,38)$ indicate that the osmoreceptors responsible for slowing of the gastric emptying rate are located in the duodenum. These receptors alter the gastric emptying rate in response to the osmotic pressure of fluids (which were previously gastric contents) in the lumen of the duodenum or small intestine (37). The inclusion of ethanol or many other solutes in a test meal will alter the gastric emptying rate (9). This alteration varies with the solute concerned. The $\left(k_{e}\right)_{\max }$ in equation 1 is equivalent to the rate constant for gastric emptying of the $150 \mathrm{ml}$ volume if no alcohol were present. Equation 1 indicates that the value of $k_{e}$ will decrease as the dose of alcohol increases. An arrow from $S$ to $B$, indicating that some of the alcohol is absorbed from the stomach directly, as some literature suggests, was not included in the model. Since only the $B$ compartment was sampled, there was insufficient information to determine what fraction of the absorbed dose went directly from $S$ to $B$ and what fraction went from $S$ via $I$ to $B$.

The results of the simultaneous fitting of the average blood ethanol concentration over the entire time range are shown in Table VI and Fig. 6. From the data in this table, the doses of alcohol administered, and equation 1 , the values of $k_{c}$ calculated were $3.30,1.09,0.514$, and $0.293 \mathrm{hr}^{-1}$ for doses of $15,30,45$, and $60 \mathrm{ml}$ of $95 \%$ alcohol, respectively. The estimated value of $k_{a}, 25.1 \mathrm{hr}^{-1}$, is very large compared with these rate constants for gastric emptying. Thus the results suggest that (a) once alcohol reaches the small intestine its absorption is extremely rapid, (b) observed blood levels of ethanol following oral administration are mainly controlled by gastric emptying rate and Michaelis-Menten elimination kinetics, and (c) there is essentially complete absorption and systemic availability of the entire dose of alcohol (since $F=1$ for 45 and $60 \mathrm{ml}$ doses and $F=0.96$ for the $30 \mathrm{ml}$ dose), except possibly at very low doses (since the estimated $F_{15 \mathrm{ml}}=0.785$ ). 
Table VI. Results of Simultaneous Fitting ${ }^{\alpha}$ of Average Blood Concentrations of Alcohol Over the Entire Time Range (Fasting Oral Study)

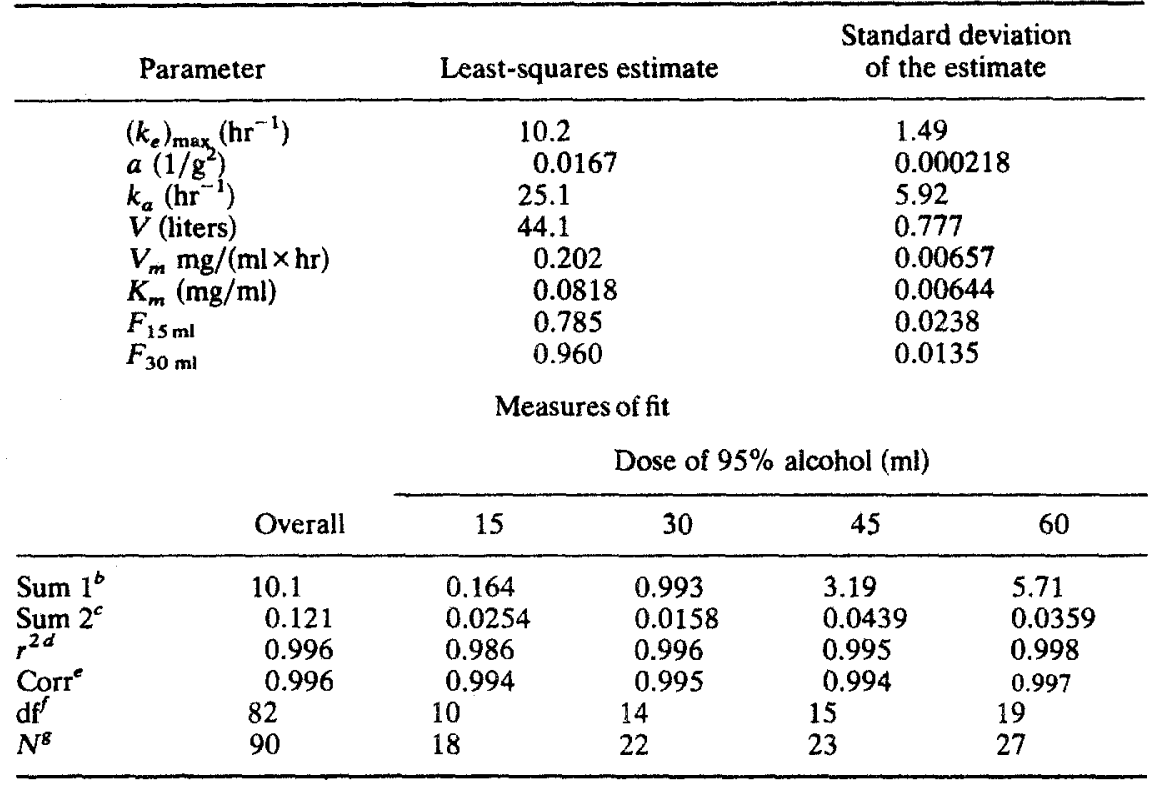

${ }^{a}$ Blood alcohol concentrations were weighted according to their reciprocals during the fitting.

${ }^{b}$ Sum $1=$ the sum of squared observations.

'Sum $2=$ the sum of weighted squared deviations.

${ }^{d} r^{2}=\left[\Sigma C^{2}-\sum(\hat{C}-C)^{2}\right] / \sum C^{2}$, where $\hat{C}$ is the model-predicted ethanol concentration.

e Correlation coefficient for the regression of model-predicted vs. observed concentration.

${ }^{f}$ Degrees of freedom.

${ }^{8}$ Number of data points in the fitting.

Although the model employed does not take it into consideration, this apparent incomplete bioavailability at the lowest dose could have been caused by a "first-pass" phenomenon, which becomes saturated at relatively low doses of alcohol, but is unimportant at higher doses; however, the result could also have been caused by use of mean blood concentrations and inherent uncertainty of estimated parameters.

The estimated value of $V$ (44.1 liters) in Table VI is $59.1 \%$ of the average body weight of the panel of subjects $(74.6 \mathrm{~kg}$ ) (see Table III). The average value of $V$, obtained by individual fitting of other subjects' pre- and postinfusion data to the one-compartment open model with zero-order input and Michaelis-Menten elimination, was 42.7 liters or $53.5 \%$ of body weight, but this panel of six subjects had an average body weight of $80.1 \mathrm{~kg}$ (39). Both these values agree with values given for total body water, the estimates of which are quite variable and depend on both age and body weight (40). 


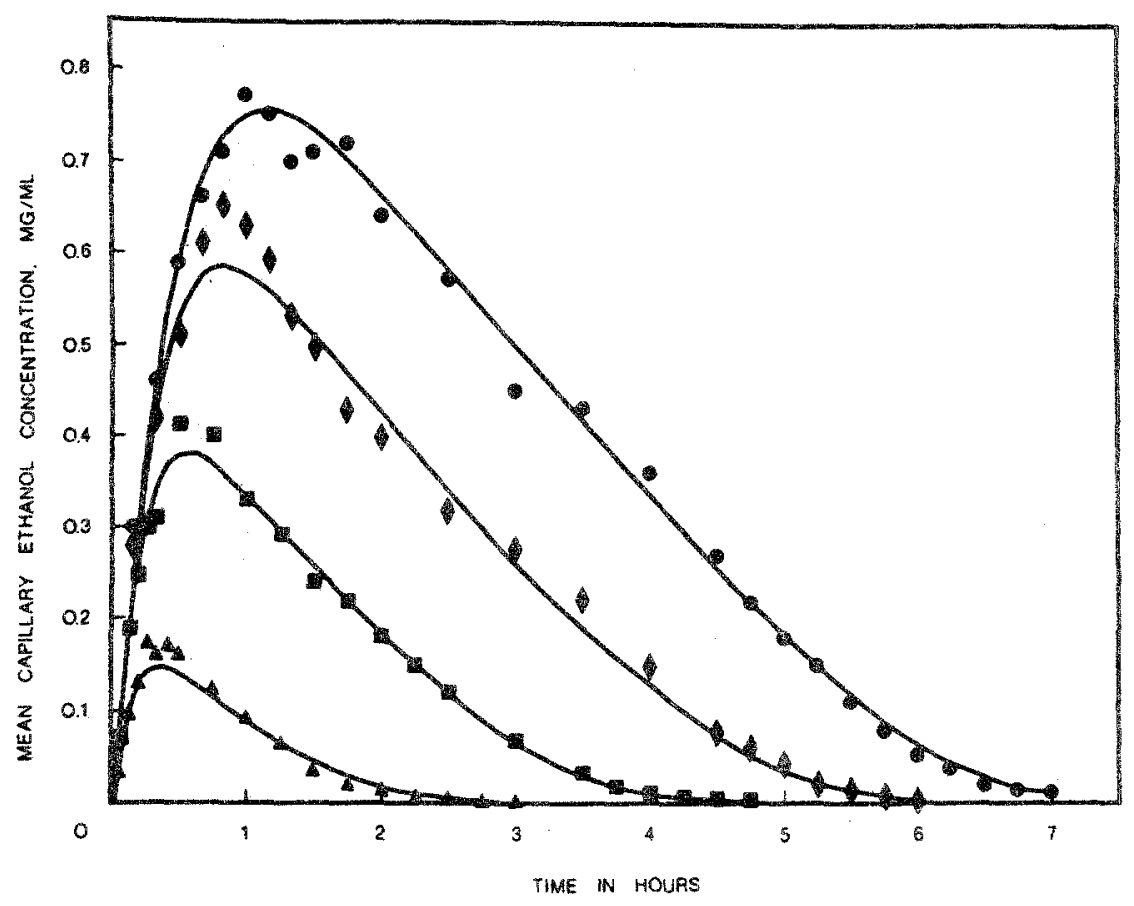

Fig. 6. Observed (points) vs. model-predicted (lines) mean capillary ethanol concentrations following the oral administration of four different doses of ethanol to eight adult male subjects. For key, see caption of Fig. 1.

The estimated value of $V_{m}, 0.202 \mathrm{mg} /(\mathrm{ml} \times \mathrm{hr})$, is very similar to the average value of 0.232 for the six other subjects given alcohol by constantrate intravenous infusion. The estimated value of $K_{m}, 0.0818 \mathrm{mg} / \mathrm{ml}$, is almost identical to the average value of 0.0821 obtained in the same study (39).

Reevaluation of the data of Hunt and Macdonald (6) by regressing the half-life of gastric emptying of 39 pectin meals on the volume of the test meal gave an extrapolated estimate of $4.67 \mathrm{~min}$ for the half-life of gastric emptying of a meal of $150 \mathrm{ml}$ volume, which was used in our study; the corresponding first-order rate constant $\left(k_{e}\right)$ is $8.9 \mathrm{hr}^{-1}$. When the corresponding $39 k_{e}$ values of Hunt and Macdonald were evaluated by regressing $\ln k_{e}$ on $\ln V^{*}$, where $V^{*}$ is the volume of the test meal, the extrapolated estimate of $k_{e}$ was $13 \mathrm{hr}^{-1}$ for a $V^{*}$ value of $150 \mathrm{ml}$. Therefore, these two values, 8.9 and $13 \mathrm{hr}^{-1}$, obtained by two different methods, for a $150 \mathrm{ml}$ volume, bracket the value of $10.2 \mathrm{hr}^{-1}$ for $\left(k_{e}\right)_{\max }$, which would be the predicted gastric emptying rate constant for $150 \mathrm{ml}$ of water containing no alcohol. 
Thus the model (Scheme I) gave parameter estimates consistent with those obtained from intravenous infusion studies (29) and with data reported in the literature concerning the stomach emptying rate of liquid meals.

There are certain deficiencies in the preliminary model (Scheme I and equations 1-3). These are as follows: (a) Appreciable amounts of alcohol are absorbed from the human stomach (41), but the model ignores this. Without simultaneous sampling in compartments $S$ and $B$ of Scheme I, one could not accurately estimate the fractions of the absorbed dose involved in direct $S$ to $B$ and $S$ via $I$ to $B$ pathways. (b) Small percentages (1-5\%) of the alcohol in the body are excreted unchanged in the urine and via the lungs in the breath. The model ignores these routes of excretion. Without simultaneous sampling of urine, the breath and blood rate constants involved in these processes could not be estimated. Although Fig. 6 indicates that the model-predicted concentrations near the peak represent the observed data very well for the highest dose, they underestimate the observed data for the three lowest doses. (c) Although the one-compartment open model with MichaelisMenten elimination kinetics reasonably well predicted alcohol blood concentrations both during and following constant-rate infusions of ethanol in six out of seven normal volunteers (39), there is also evidence of multicompartmental pharmacokinetics for ethanol in man in that the time courses of venous and capillary alcohol concentrations are different (42). (d) Equation 1 , used to estimate the rate constant for stomach emptying of alcohol, $\boldsymbol{k}_{e}$, from the dose of alcohol administered, is empirical. In future studies in man if isotopically labeled ethanol is utilized, if stomach emptying is monitored by external scanning, and if alcohol is estimated in urine, breath, and venous and arterial (or capillary) blood, then the resulting data will most probably allow considerable improvement on the preliminary model.

\section{REFERENCES}

1. D. R. Laurence, Clinical Pharmacology, 3rd ed., J. Churchill and A. Churchill, London, 1966, p. 283.

2. J. E. Finch, M. J. Kendall, and M. Mitchard. An assessment of gastric emptying by breathanalyser. Br. J. Clin. Pharmacol. 1:233-236 (1974).

3. W. W. Westerfeld and M. P. Schulman. Metabolism and caloric value of alcohol. J. Am. Med. Assoc. 170: 197-203 (1959).

4. T. Chang and A. J. Glazko. Effects of ethanol on intestinal amino acid transport. In M. A. Rothschild, M. Oratz, and S. S. Schreiber (eds.), Alcohol and Abnormal Protein Bile Synthesis, Biochemical and Clinical, Pergamon Press, New York, 1975, pp. 95-110.

5. E. Mellanby. Alcohol and alcoholic intoxication. Br. J. Inebriety 17:157-178 (1920),

6. J. N. Hunt and I. Macdonald. The influence of volume on gastric emptying. J. Physiol. 126:459-474 (1954).

7. E. Mellanby. Alcohol; Its Absorption into and Disappearance from the Blood Under 
Different Conditions, Medical Research Council, Special Report Service, No. 31, HMSO, London, 1919.

8. H. H. Mitchell and E. G. Curzon. The food value of ethyl alcohol. J. Strud. Alcohol 1:227-245 (1940).

9. J. N. Hunt and J. D. Pathak. The osmotic effects of some simple molecules and ions on gastric emptying. J. Physiol. 154:254-269 (1960).

10. W. W. Jetter, Studies on alcohol. II. Experimental feeding of alcohol to non alcoholic individuals. Am. J. Med. Sci. 196:487-493 (1938).

11. C. F. Cori, E. L. Villiaume, and G. T. Cori. Studies on intestinal absorption. II. The absorption of ethyl alcohol. J. Biol. Chem. 87:19-25 (1930).

12. F. R. Sidell and J. E. Pless. Ethyl alcohol: Blood levels and performance decrements after oral administration to man. Psychopharmacologia 19:246-261 (1971).

13. H. W. Southgate. CXIII. The effect of alcohol, under varying conditions of diet, on man and animals, with some observations on the fate of alcohol in the body. Biochem. $J$. 19:737-745 (1925).

14. L. Goldberg. Behavioral and physiological effects of alcohol on man. Psychosom. Med. 28:570-595 (1966).

15. E. M. Sellers, M. Lang, J. Koch-Weser, E. LeBlanc, and H. Kalant. Interaction of chloral hydrate and ethanol in man. 1. Metabolism. Clin. Pharmacol. Ther. 13:37-49 (1973).

16. G. P. Mould, S. H. Curry, and T. B. Binns. Interaction of glutethimide and phenobarbitone with ethanol in man. J. Pharm. Pharmacol. 24:894-899 (1972).

17. R. N. Harger, R. B. Forney, and R. S. Baker. Estimation of the level of blood alcohol from analysis of breath. II. Use of rebreathed air. J. Stud. Alcohol 17:1-18 (1956).

18. M. A. Evans, R. Martz, B. E. Rodda, G. F. Kiplinger, and R. B. Forney. Quantitative relationship between blood alcohol concentration and psychomotor performance. Cin. Pharmacol. Ther. 15:253-260 (1974).

19. R. B. Forney, F. W. Hughes, R. N. Harger, and A. B. Richards. Alcohol distribution in the vascular system: Concentration of orally administered alcohol in blood from various points in the vascular system, and in rebreathed air, during absorption. J. Stud. Alcohol 25:205$217(1964)$.

20. D. O. Gibbons and A. F. Lant. Effects of intravenous and oral propantheline and metoclopramide on ethanol absorption. Clin. Pharmacol. Ther. 17:578-583 (1975).

21. H. W. Haggard, L. O. Greenberg, and L. H. Cohen. Quantitative differences in the effects of alcoholic beverages. New Engl. J. Med. 219:466-470 (1938).

22. J. G. Wagner and J. A. Patel. Variations in absorption and elimination rates of ethyl alcohol in a single subject. Res. Commun. Chem. Pathol. Pharmacol. 4:61-76 (1972).

23. A. J. Sedman. Blood levels of ethanol and a decision-making pharmacokinetic digital computer program. Ph.D. dissertation, The University of Michigan, Ann Arbor, Michigan, 1974, University Microfilms No. 7510290.

24. A. J. Sedman, P. K. Wilkinson, E. Sakmar, D. J. Weidler, and J. G. Wagner. Food effects on the absorption and metabolism of ethyl alcohol. J. Stud. Alcohol. 37:1197-1214 (1976).

25. J. G. Wagner, P. K. Wilkinson, A. J. Sedman, D. R. Kay, and D. J. Weidler. Elimination of alcohol from human blood. J. Pharm. Sci. 65:152-154 (1976).

26. M. G. Eggleton. Some factors affecting the metabolic rate of alcohol. J. Physiol. $98: 239$ 254 (1940).

27. H. W. Newman, A. J. Lehman, and W. C. Cutting. Effect of dosage on rate of disappearance of alcohol from the blood stream. J. Pharmacol. Exp. Ther. 61:58-61 (1937).

28. F. Lundquist and $\mathrm{H}$. Wolthers. The kinetics of alcohol elimination in man. Acta Pharmacol. Toxicol. 14:265-289 (1958).

29. R. D. Hawkins and H. Katant. The metabolism of ethanol and its metabolic effects. Phamacol. Rev. 24:67-157 (1972).

30. N. H. Raskin. Alcoholism or acetaldehydism. New Engl. J. Med. 292:422-423 (1975).

31. P. K. Wilkinson, J. G. Wagner, and A. J. Sedman. A sensitive headspace gas chromatographic method for the determination of ethanol utilizing capillary blood samples. Anal. Chem. 47:1506-1510 (1975). 
32. C. M. Metzler. Biostatistical Technical Report 7292/69/7292/005, Upjohn Co., Kalamazoo, Mich., November 25, 1969.

33. J. G. Wagner. Properties of the Michaelis-Menten equation and its integrated form which are useful in pharmacokinetics. J. Pharmacokin. Biopharm. 1:103-121 (1973).

34. L. Michaelis and M. L. Menten. Die Kinetik der Invertinwirkung. Biochem. Z. 49:333-369 (1913).

35. J. G. Wagner and E. Nelson. Percent absorbed plots derived from blood level and/or urinary excretion data. J. Pharm. Sci. 52:610-611 (1963).

36. J. G. Wagner. Fundamentals of Clinical Pharmacokinetics, Drug Intelligence Publications, Hamilton, Ill., 1975, p. 200.

37. J. N. Hunt. The site of receptors slowing gastric emptying in response to starch in test meals. J. Physiol. 154:270-276 (1960).

38. E. Elias, G. J. Gibson, L. F. Greenwood, J. N. Hunt, and J. H. Tripp. The slowing of gastric emptying by monosaccharides and disaccharides in test meals. J. Physiol. 194:317-326 (1968).

39. P. K. Wilkinson, A. J. Sedman, E. Sakmar, R. H. Earhart, D. J. Weidler, and J. G. Wagner. Blood ethanol concentrations during and following constant rate intravenous infusion of alcohol in man. Clin. Pharmacol. Ther. 19:213-223 (1976).

40. P. L. Altmen and D. S. Dittmer (eds.). Blood and Other Body Fluids, Federation of American Societies for Experimental Biology, Bethesda, Md., 1971, pp. 496-497.

41. A. R. Cooke and A. Birchall. Absorption of ethanol from the stomach. Gastroenterology 57:269-272 (1969).

42. A. J. Sedman, P. K. Wilkinson, and J. G. Wagner. Concentrations of ethanol in two segments of the vascular system. J. Forensic Sci. 21:315-322 (1976). 